\title{
Metaphors of warfare and the lessons of history: time to revisit a carbon tax?
}

\section{An editorial comment}

\author{
Naomi Oreskes
}

Received: 22 April 2010 / Accepted: 12 May 2010 / Published online: 30 June 2010

(C) The Author(s) 2010. This article is published with open access at Springerlink.com

Maurie Cohen (Cohen 2010) revisits the world of rationing in World War II and suggests that the experience of rationing in the UK under the dire conditions of Nazi bombardment and threatened invasion may provide useful lessons as to how a cap and trade system to control and reduce carbon emissions might work in a world of dire climate change. Cohen's argument is triggered in part by the use of warfare metaphors by leading politicians and journalists to command public attention over the looming dangers of unmitigated climate change. To be sure, the scientific evidence is overwhelming that if left unchecked, increased atmospheric greenhouse gas concentrations and decreased global forestation will lead to significant changes in the Earth's climate, ecosystems, and ocean chemistry (Solomon et al. 2007; see also Oreskes 2004). Among other things, we can expect major human dislocations from sea level change and altered patterns of precipitation (Stern et al. 2006; Parry et al. 2007). Such impending difficulties—and the relative inaction and complacency of much of the world in the face of them-has caused some leaders to turn to the metaphor of warfare to convey the urgency of the situation, and to suggest that the need for a cap and trade system with strict limits on corporate and personal carbon use has now reached the level of an emergency.

\section{Is warfare the right metaphor?}

Is warfare the right metaphor? Will it help? Will it work? Cohen argues that the warfare metaphor is intended in part to overcome resistance: to convey a sense of urgency that will cause citizens to awake from their complacent slumbers and accept the need for action. But resistance has many causes, one of which is the widespread human desire to avoid unpleasantness. It could be that the analogy of warfare-with all its unpleasant associations-might trigger the very anxiety and resistance it is intended to overcome.

N. Oreskes $(\bowtie)$

University of California, San Diego, CA, USA

e-mail: naoreskes@ucsd.edu 
Former US Vice President Al Gore has popularized the notion of inconvenient truths, but scientists have recognized for some time that both the general citizenry and government leaders are often loath to accept scientific evidence whose conclusions are awkward or unpleasant. In 1949, when the USSR detonated its first atomic bomb, the USA had to face the grim reality that it had lost its monopoly on nuclear weapons. Scientists had been warning since 1945 (and even before) that the notion of a nuclear monopoly was misguided, that nature has no secrets and an intelligent adversary would soon be able to build an atomic bomb, too. This warning was largely ignored, until the events of 1949 proved it prescient. However, the success of their predictions did not increase scientists' standing. One the contrary, when scientists now said that any attempt to one-up the Soviets by building the H-bomb would simply accelerate the arms race, they were accused of being disloyal. As the chemist Harold Urey, 1934 Nobel Laureate for his discovery and isolation of deuterium, wrote: "We scientists not only failed to convince Congress and the public of the soundness of our prediction that the Russians would have the bomb in about five years after we had it, but, because we told disagreeable truths, we have even been accused of wishing to give up our progress because we are impractical dreamers or plain traitors." (Urey 1949, quoted in York 1976, on p. 43).

What is most disagreeable to many "resistors" (as I shall call those who resist the scientific evidence of anthropogenic global warming) is the fear of coercive government: that the threat of severe climate change and unmanageable sea level rise will be used as warrant for heavy-handed government intervention in national and even global economic activity, and perhaps control of individual activities, as well (Oreskes and Conway 2010). Indeed, there is an uncanny parallel with the events of 1949: fear of the Soviet Union in 1949 was not about a potential Soviet invasion of mainland America, which was clearly not within the realm of Soviet capability, or even that they would bomb us into obliteration (although that anxiety would come later). It was, rather, that the Soviets would export communism to Europe, from which it would spread, perhaps, into the USA as well, and we would all soon live under the communist yoke. Today, American conservatives and right-wing commentators have re-awakened the beast of red-baiting, as when columnist Charles Krauthammer recently alleged that environmentalism is socialism by other means: "With socialism dead...the Left was adrift until it struck upon a brilliant gambit: metamorphosis from red to green" (Krauthammer 2009). Or consider the recent claim of Patrick Michaels, a longtime critic of climate science and some-time policy scholar at the libertarian Cato Institute, who criticized plans for a cap and trade system to control greenhouse gases as "Obamunism" (Michaels 2009).

Warfare is seen by both liberals and conservatives as legitimate basis for government action that would otherwise be intolerable, so the warfare metaphor may suggest the very coercion that resistors most fear. Therefore, it may not be the best metaphor for finding and sustaining a political middle ground.

\section{Is global warming an emergency?}

It is hard to imagine anyone who would not argue that opened armed conflict constitutes a national emergency and therefore justifies emergency measures. This, of course, was precisely the justification for rationing during World War II, and, 
as Cohen notes, the vast majority of British citizens accepted its necessity (and similarly, resisted its continuance after overt hostilities had ended). Fraud and black marketeering occurred, to be sure, but they were remarkably rare: Cohen cites the work of Zweiniger-Bargielowska (2000) who estimates black market transactions as accounting for only $10 \%$ of total automobile use. That is a very low number; even if the real figure was twice that, it means that the vast majority of citizens largely respected the rationing system.

But is climate change an emergency? The Oxford English Dictionary defines the term as a situation "urgently demanding immediate action." It also notes the common association with warfare: "as a political term, to describe a condition approximating to that of war; ... as a synonym or euphemism for war; also state of emergency, wherein the normal constitution is suspended."1

Why is action required immediately in an emergency? The dictionary does not say, but most of us understand the implication that if immediate action is not taken, serious harms will directly ensue. A fire is an emergency because if we don't leave the building we may burn or perish from smoke inhalation; a heart attack, a drowning, or a man lost overboard at sea is an emergency, too. The implication is one of impending death, or at least serious bodily harm; the further implication is that immediate action-such as calling the fire department or throwing out a lifelinecan be efficacious to prevent the harm. There is also an implication of certainty: there is no doubt that a man lost at sea, if not quickly rescued, will surely drown. Finally most of us view emergencies as involving people. If avian flu swept the USA, killing tens of thousands, it would be viewed as an emergency, but if the same flu killed tens of thousands of pet parakeets, it would probably be viewed as very sad, but not an emergency.

At the risk of being quoted out of context, I would suggest that climate change is not, in fact, an emergency, as conventionally understood. As Cohen correctly notes, "atmospheric warming lacks the immediacy and tangibility of aerial bombardment..." Serious harms will eventually ensue if we fail to act, but the harms are not, by and large, immediate. And because the harms will be unfolding over the next several decades, or even centuries, even if we do act now, our actions will not show immediate effects. Moreover, many of the expected harmful effects-such as ocean acidification-are not well understood. They may precipitate a chain of undesirable events whose adverse consequences eventually reach human populations, but how that will happen and who among us will be affected remains uncertain. And many of the harms will accrue to non-human species.

\section{Cap and trade as a form of rationing}

Cohen argues that a cap and trade system is essentially a form of rationing, and so the lessons of history can help us to plan our cap and trade system. Among other things, we should be prepared for fraud and black-marketeering, and to adjust regulations to respond to changing circumstances. (He might also have added that we should be

\footnotetext{
${ }_{1}^{1} \mathrm{http}: / /$ dictionary.oed.com/cgi/entry/50073965? single=1\&query_type=word \&queryword= emergency\&first $=1 \&$ max_to_show $=10$
} 
prepared for serious resistance, including riots.) We should also realize that citizens will tolerate sacrifice only for a limited period of time, during which a clear end is in sight.

Cohen's conclusions are reasonable, but there is another possible reading of his evidence. Rather than take the lessons of history to suggest how to plan and manage our cap and trade systems, we might take them to suggest that cap and trade may not be the right approach after all.

If climate change is not a war, and we are not in an emergency, then the lessons of history suggest that citizens will not be willing to accept serious sacrifices to stop it. The situation would have to become extremely dire-with the threat of imminent death-before rationing would become acceptable, and by that time the changes underway would almost certainly be impossible to stop (if they are not in fact too late to stop already: Meehl et al. 2005; Wigley 2005; Solomon et al. 2007; Stainforth et al. 2007; Ramanathan and Feng 2008; Hansen 2009).

Because climate change will now be with us for the foreseeable future, it is hard to see it as a condition that will justify the suspension of "the normal constitution," and hard to see how people can be mobilized to accept emergency measures to address it. Climate change will become the new normal. Therefore, whatever mechanism is used to address it has to be normal, too. The most likely mechanism that fits that bill is a carbon tax. Whatever you say about taxes, no one can deny that they are normal.

\section{Carbon tax as a normal mechanism to stop climate change}

Carbon taxes have been under discussion for some time. Indeed, in the early 1980s, economists working with the National Academy of Sciences Climate Research Board, including Nobel Laureate Thomas Schelling, explicitly considered a carbon tax as a mechanism for mitigating global warming. At that time, Schelling and his colleagues rejected the idea on the grounds that the tax required to affect energy use would be very large, politically unacceptable, and possibly economically destructive. Given that the physical impacts of predicted warming were at that time highly uncertain, and the likely social impacts even more uncertain, Schelling and his colleagues concluded that the best response at that time was to wait and see how matters developed, and, if necessary, to adapt to changes as they unfolded (Schelling 1980).

At about that same time, cap and trade mechanisms were being considered as a possible response to sulfur pollution implicated in acid precipitation, and for dealing with air pollution in the Los Angeles basin (South Coast Air Quality Management District 1994; Young 1996; Bryner 1997; Kamieniecki et al. 1999; Moore 2003). As an alternative to command and control solutions to pollutions, cap and trade was viewed as congenial by many political moderates and conservatives for addressing global warming as well, because it drew on market concepts, promised consumers (particularly industrial consumers) more flexibility than they might otherwise have had, and appeared more politically palatable than a carbon tax.

However, as economists studied possible responses to global warming, many came to the conclusion that, despite the political attractiveness of cap-and-trade, a properly valued carbon tax might be a more efficient and effective mechanism to 
reduce greenhouse gas emissions. (And taxes, of course, are also a market-based mechanism, insofar as they adjust the price of a good or service.) Yale economist William Nordhaus (who ironically was a member of the 1983 NRC study team), argued in several papers over nearly two decades that an appropriately set, revenueneutral carbon tax could be an effective means of reducing greenhouse gas emissions and would likely be more efficient than an emissions stabilization and trading regime (Nordhaus 1993a, b, 1997, 2005, 2006, 2007). Others have made similar arguments (Repetto et al. 1992; Parry et al. 1999; Shackleton et al. 1993; Cooper 2007; Metcalf and Weisbach 2009; see also Pearce 1991, for an early summary of the advantages and disadvantages of carbon taxes versus alternatives; and Stavins 2009, and Krugman 2010 for more recent comparisons). Recently, Nordhaus has made this argument even more emphatically. At a presentation at a major international conference in Copenhagen prior to the 2009 COP 15 meeting, Nordhaus argued that a carbon tax would be the most effective and efficient incentive to shift the world to a low carbon economy. "Taxation is a proven instrument. Taxes may be unpopular, but they work," he concluded. ${ }^{2}$

However, while there appears to be sound scholarly justification for carbon taxes, politically taxes are anathema to many Americans, and in the dominant neo-liberal policy environment of the late 1980s and 1990s, policy solutions focused on cap-andtrade as a more desirable mechanism (Schneider 2009; Oreskes and Conway 2010). (It is thus ironic that conservatives in the United States are now objecting to capand-trade as burdensome and bureaucratic, requiring large degrees of government involvement in compliance and verification, when the very idea was developed as a means to avoid burdensome government taxation. ${ }^{3}$ )

To return to Nordhaus's claim that taxation is a proven instrument, we might reply, "proven for what?" Proven for raising revenues, to be sure, but proven for protecting the environment? That is not so clear. On the other hand, our experiences with cap-and-trade are not unambiguous, either. The US experience of controlling acid precipitation is often held up as a model of successful environmental regulation through market mechanisms, but the fact is that while acid precipitation was reduced significantly, it is not clear that it was reduced enough. While diverse groups declared victory, and moved on to other matters, the US and Canadian forests continued to decline (Likens and Franklin 2009; see discussion in Oreskes and Conway 2010).

Available analyses and experience suggest that both cap-and-trade systems and carbon taxes have the capacity to reduce greenhouse gas emissions and slow global climate change, and both face significant challenges (Stavins 2009; Krugman 2010). Either system will require enforcement mechanisms, compliance verification, and monitoring of effects. Taxes may be simple in principle, but one need only look at the American tax code to see what can happen in practice. Emissions trading may harness the power of the marketplace, but that does not ensure that our environmental goals will be met.

Moreover, both systems entail profound uncertainties. Advocate of emissions trading often argue that this mechanism is preferable, because in a taxation regime

\footnotetext{
${ }^{2}$ http://www.guardian.co.uk/environment/2009/mar/12/carbon-tax-should-replace-kyoto-protocol

${ }^{3}$ See for example http://spectator.org/blog/2009/06/25/congress-should-stop-al-gores.
} 
you do not know how people will respond to the tax, and therefore have no guarantee that you will achieve the desired level of control on atmospheric GHGs. This is true. However, in an emissions trading system, you do not know how the environment will respond. Even if we effectively control anthropogenic $\mathrm{CO}_{2}$ by setting strict emissions limits, continued warming could melt the tundra and release substantial amounts of natural methane. In either case, scientific monitoring will be required to determine the actual content of GHGs in the atmosphere.

If history is any guide, the most likely outcome is that either system will prove too weak, and will have to be tightened and strengthened over time. So one question to consider is this: is it likely to prove easier to lower the caps in a cap and trade system or to raise the tax in a taxation regime?

This question is hard to answer, since we have relatively little experience with cap-and-trade systems. However, if we think of a carbon tax as a kind of sin taxequivalent to the taxes on alcohol and tobacco-we might note that, despite the general American animadversion to taxes, it has actually proved relatively easy to increase these taxes, indeed, to increase them a great deal. Once the public accepted that smoking was truly dangerous, opposition to heavy taxation fell away rapidly, and today tobacco taxes are exceedingly high and an enormous source of governmental revenues. It may well be that once the public begins to accept that uncontrolled climate change will indeed be dangerous, they may also accept that substantial "sin" taxes on carbon make sense.

Finally, to return to Cohen's arguments, we can see one crucial potential benefit of a revenue-neutral carbon tax: Once implemented, it will become part of life like any sales tax, VAT, or other tax imposed at the point of purchase. It does not require any special appeal to patriotism, exigency, camaraderie or any other virtue. It does not require altruism. No one pretends that tax, any more than death, is a good thing, but most of us (with some exceptions), accept that taxes are necessary for civil society to function. We accept that taxes are normal. ${ }^{4}$ We need not invoke metaphors of warfare or questionable claims of emergency and crisis. We just have to acknowledge, as we do with the other forms of taxation with which most of us routinely comply, that it is necessary.

Acknowledgements Thanks to Erik M. Conway and Richard Somerville for helpful suggestions on an earlier version of this comment.

Open Access This article is distributed under the terms of the Creative Commons Attribution Noncommercial License which permits any noncommercial use, distribution, and reproduction in any medium, provided the original author(s) and source are credited.

\section{References}

Bryner G (1997) Market incentives in air pollution control. In: Kamieniecki S, Gonzales GA, Vos RO (eds) Flashpoints in environmental policy-making: controversies in achieving sustainability. SUNY Press, Albany, pp 85-107

\footnotetext{
${ }^{4}$ It could also be argued that markets are normal, and therefore what the advocates of cap and trade need to do is emphasize their character as ordinary markets and avoid any possible suggestion that they are a form of rationing. Therefore politicians would be advised not to invoke the metaphor of warfare. That would have been a different response to Cohen's paper.
} 
Cohen MJ (2010) Is the UK preparing for 'war'? Military metaphors, personal carbon allowances, and consumption rationing in historical perspective. Clim Change. doi:10.1007/s10584-009-9785-x

Cooper RN (2007) Alternatives to Kyoto: the case for a carbon tax. In: Aldy JE, Stavins RN (eds) Architectures for agreement, addressing global climate change in the Post-Kyoto World. Cambridge University Press, Cambridge

Hansen JE (2009) Storms of my grandchildren: the truth about the coming climate catastrophe and our last chance to save humanity. Bloomsbury, New York

Kamieniecki S, Shafie D, Silvers J (1999) Forming partnerships in environmental policy: the business of emissions trading in clean air management. Am Behav Sci 43(1):107-123

Krauthammer C (2009) "The new socialism," Washington post. http://www.washingtonpost.com/ wp-dyn/content/article/2009/12/10/AR2009121003163.html. Accessed 11 Dec 2009

Krugman P (2010) Building a green economy. The New York Times Magazine. www.nytimes.com/ 2010/04/11/magazine/11Economy-t.html?pagewanted=print. Accessed 11 Apr 2010

Likens GE, Franklin JF (2009) Ecosystem thinking in the Northern Forest. Bioscience 59(6): $511-513$

Meehl GA, Washington WM, Collins WD, Arblaster JM, Hu A, Buja LE, Strand WG, Teng H (2005) How much more global warming and sea level rise? Science 307:1769-1772

Metcalf GE, Weisbach D (2009) The design of a carbon tax. Harvard Environ Law Rev 33:499-556

Michaels PJ (2009) Cap and- trade is dead. Long live cap- and- trade, Cato institute. http://www.cato. org/pubdisplay.php?pub_id=10558. Accessed 18 Sep 2009

Moore CA (2003) RECLAIM: southern California's failed experiment with air pollution trading. http://healthandcleanair.org/emissions/reclaim.pdf

Nordhaus WD (1993a) Rolling the DICE: an optimal transition path for controlling greenhouse gases. Resour Energy Econ 15(1):27-50

Nordhaus WD (1993b) Optimal greenhouse gas reductions and tax policy in the DICE model. Am Econ Rev 83(2):313-317

Nordhaus WD (1997) Economic growth and climate: the carbon dioxide problem. American Economic Review, Papers and Proceedings of the Eighty-ninth Annual Meeting of the American Economic Association 67(1):341-346

Nordhaus WD (2005) Life after Kyoto: approaches to global warming policies. On line at www. econ.yale.edu/ nordhaus/homepage

Nordhaus WD (2006) Life after Kyoto: alternative mechanisms to control global warming. American Economic Review, Papers and Proceedings of the Eighty-ninth Annual Meeting of the American Economic Association 96(2):31-34

Nordhaus WD (2007) To tax or not to tax: Alternative approaches to slow global warming. Review of Environmental Economics and Policy 1(1):26-44

Oreskes N (2004) The scientific consensus on climate change. Science 306:1686

Oreskes N, Conway EM (2010) Merchants of doubt: how a handful of scientists obscured the truth on issues from tobacco smoke to global warming. Bloomsbury, New York

Parry IWH, Williams RC III, Goulder LH (1999) When can carbon abatement policies increase welfare? J Environ Econ Manage 37:52-84

Parry ML, Canziani OF, Palutikof JP, van der Linden PJ, Hanson CE (2007) Climate change 2007: impacts, adaptation and vulnerability. Contribution of working group II to the fourth assessment report of the Intergovernmental Panel on Climate Change. Cambridge University Press, Cambridge, on line at http://www.ipcc.ch/pdf/assessment-report/ar4/wg2/ar4-wg2-spm.pdf

Pearce D (1991) The role of carbon taxes in adjusting to global warming. Econ J 101(407):938-948

Ramanathan V, Feng I (2008) On avoiding dangerous anthropogenic interference with the climate system: formidable challenges ahead. Proc Natl Acad Sci 105:14245-14250

Repetto R, Dower RC, Jenkins R, Geohegan J (1992) Green fees: how a tax shift can work for the environment and the economy. The World Resources Institute, Washington

Schelling TC (1980) Climate Research Board, 18 April 1980. Collection, National Academy of Sciences, National Academies Archive, Washington, DC

Schneider SH (2009) Science as a contact sport. National Geographic Press, Washington

Shackleton R, Shelby M, Cristofaro A, Brinner R, Yanchar J, Goulder L, Jorgenson D, Wilcoxen P, Pauly P, Kaufman R (1993) The efficiency value of carbon tax revenues. Energy Modeling Forum, Terman Engineering Center, Stanford University, Stanford

Solomon S, Qin D, Manning M, Chen Z, Marquis M, Averyt KB, Tignor M, Miller HL (eds) (2007) Climate Change 2007: the physical science basis. Contribution of working group I to the fourth assessment report of the Intergovernmental Panel on Climate Change. Cambridge University Press, Cambridge, United Kingdom and New York, NY, USA, on line at http://ipccwg1.ucar.edu/wg1/wg1-report.html 
South Coast Air Quality Management District (1994) RECLAIM program summary: a market incentive air pollution reduction program for $\mathrm{NO}_{\mathrm{x}}$ and $\mathrm{SO}_{\mathrm{x}}$. South Coast Air Quality Management District, Diamond Bar

Stainforth DA, Downing TE, Washington R, Lopez A, New M (2007) Issues in the interpretation of climate model ensembles to inform decisions. Philos Trans R Soc Part A 365:2163-2177

Stavins R (2009) Can countries cut carbon emissions without hurting economic growth? Confusion in the Senate regarding allowance allocation: cap and trade versus the alternatives for the U.S. climate policy. An economic view of the environment (website) http://belfercenter.ksg. harvard.edu/analysis/stavins/ $?=\mathrm{p}=355 \#$

Stern N et al (2006) Stern review on the economics of climate change. http://webarchive. nationalarchives.gov.uk/+http:/www.hm-treasury.gov.uk/sternreview_index.htm

Wigley TML (2005) The climate change commitment. Science 307:1766-1769

York HF (1976) The advisors: oppenheimer, teller, and the superbomb. Stanford University Press, Stanford

Young HN (1996) An analysis of global $\mathrm{CO}_{2}$ emissions trading program. J Land Use Environ Law 14(1). http://www.law.fsu.edu/Journals/landuse/vol141/you.htm

Zweiniger-Bargielowska I (2000) Austerity in Britain: rationing, controls and consumption 19391955. Oxford University Press, New York 